\title{
Economie, techniek en organisatie
}

Prof. Dr. B. Nooteboom

Onze economie vergt aan handel gerelateerde diensten en industrie. Na verwaarlozing van techniek en markten in het verleden lopen we van de weeromstuit nu het risico dat we uit het ong verliezen dat zow'el techniek als markten verw'even zijn met vraagstukken van organisatie. In markten zijn er vraagstukken van organisatie in de vorm van instituties die nodig zijn om markten te laten werken en om coördinatieproblemen op te lossen. In bedrijven zijn er vragen van organisatie in 'lenige' produktie en levering, en in de architectuur van netwerken van samenwerking. We moeten economie, techniek en organisatie met elkaar integreren.

De economie van Nederland is in belangrijke mate gebaseerd op aan de handel gerelateerde diensten: logistieke diensten van havens, overslag, transport, en daaraan verbonden diensten van groothandel, informatie, communicatie, financiering en verzekering. Dat gaat terug tot ons succesvolle verleden als handelsnatie in de zeventiende eeuw' (o.a. de VOC). Ons handelsverleden heeft geleid tot een late start van industrialisatie, en dat is nog steeds terug te vinden in een industrie die in verhouding tot andere landen wat eenzijdig is. Niettemin hebben we ook in delen van de industrie een niet te verwaarlozen kracht, die we kunnen versterken. Naast diensten hebben we de industrie ook nodig. al was het alleen als klant en als leverancier van technologie voor een deel van die diensten. Het is onzin om te praten over een keuze tussen ofwel industrie of diensten voor Nederland. We hebben ze beide nodig en ze zijn met elkaar verweven. Ze gaan ook meer op elkaar lijken: we zien een verdienstelijking van de industrie en een industrialisatie van de dienstverlening.
In zowel diensten als industrie is de toepassing van techniek in goederen, diensten en produktie van doorslaggevend belang. Het Japanse succes heeft onze ogen daarvoor heropend. Wat laat en tegen een hoge prijs: bepaalde takken van produktie zijn we kwijt en het is zeer. twijfelachtig of we die nog terug kunnen halen. Het is derhalve goed dat in het beleid van het ministerie van Economische Zaken al enige jaren meer aandacht aan techniek wordt gegeven. We hebben goede technische universiteiten, en die kracht moeten we behouden en versterken. Het is ook goed om aandacht te vragen voor technische heroepen, en om die aantrekkelijk te maken.

In het verleden hebben we markten te weinig ruimte gegeven, door te weinig ruimte en beloning voor ondernemend initiatief. Te veel praat over verdeling van de koek en te weinig over vergroting ervan. Te veel belemmerende regelingen. maar ook te veel praat over de hoge loonkosten in plaats van daden van vernieuwend ondernemerschap.

Terecht dus meer aandacht voor techniek en markt. Maar moderne ideeën over wat techniek en markt inhouden en vergen zijn onvoldoende doorgedrongen.

Het Japanse succes is niet gelegen in pure techniek, maar in de organisatie daarvan. Om te produceren zonder vorraden, goed gebruik te

Prof. Dr. B. Nooteboom is hoogleraar bedrijfskunde en is dezer dagen benoemd tot directeur van de onderzoekschool SOM (Systemen, Organisatie en Management) van de faculteiten Bedrijfskunde, Economie en Ruimtelijke Wetenschappen van de Rijksuniversiteit Groningen. 
maken van de specificke competenties van leveranciers, activiteiten op elkaar af te stemmen, produktontwikkeling te versnellen. Dat belang van organisatie is niet nieuw': men vindt het terug in alle lange golven van economische ontwikkeling. Zeker, het succes van de Verenigde Oost-Indische Compagnie, in onze gouden eeuw, was deels gebaseerd op de technologie van scheepsbouw en navigatie, maar zeker niet in de laatste plaats ook op de uitvinding van verhandelbare aundelen als middel van financiering en spreiding van de enorme risico's van een vaart op Indië. De eerste industriële revolutie werd gedragen door technologie van textiel, ijzer en waterkracht, maar ook door organisatie in de vorm van vennootschappen van technici en financiers. De tweede revolutie was gebaseerd op kolen, stoomenergie, spoorlijnen. schepen en machines. Maar de schaalvergroting die nodig was om dat potenticel te benutten was onmogelijk zonder gebruik van naamloze vennootschappen en aandelenmarkten. De daarop volgende opkomst van elektriciteit, auto's, staal en chemie vergde, wederom ter wille van schaalvergroting, organisatievormen met verschillende niveaus van bestuur. De daarop volgende golf werd gedragen door olie, massaproduktie en luchtvaart, maar ook de uitvinding van de divisiestructuur en multinationale ondernemingen. $\mathrm{Nu}$. in de huidige transformatie op basis van informatie- en communicatietechnologie, nieuwe materialen en biotechnologie, tekent zich de behoefte af aan wisselende netwerkstructuren van bedrijuen die deels samenwerken en deels rivaliseren. In de opeenvolging van economische revoluties loopt naast de lijnen van technologie en organisatie ook een lijn die te maken heeft met de overbrugging van afstand: zeilvaart. schuiten en koetsen, spoorwegen, stoomvaart, auto's en telecommunicatie, tot op de "elektronische snelweg" van nu.

In de huidige constellatie is organisatie niet meer alleen, en zelfs niet meer in de eerste plaats, een kwestic van het ontwerpen van taakverdeling en toezien op de efficiënte uitvoering daarvan, maar het stimuleren en begeleiden van verandering door het mobiliseren en kanaliseren van kennis, ervaring en inventiviteit. Vroegere staffuncties hadden de rol van het vergaren en verdelen van informatie, maar met de huidige informatietechnologie communiceren mensen direct met elkaar. Beperkingen van tijd en ruimte spelen in de communicatie vaak geen rol. Dat leidt tot ons nationale dilemma met betrekking tot de "globalisatie".

Het woord 'globalisatie' is overigens niet alleen lelijk, maar ook verkeerd. Niet "globaal" maar "mondiaal" is de juiste vertaling van het Engelse woord "global". "Globaal" betekent "ruw' geschat" of "onprecies", en dat is nu net waar het niet om gaat. Het gaat er juist om dat bedrijven heel precies moeten voldoen aan de gedifferentieerde, geïndividualiseerde vraag van verschillende mensen in verschillende landen, maar wel met goed gebruik van overeenkomsten on schaalvoordelen van mondialisering te realiseren.

Het dilemma van de mondialisering voor de overheid is dat ze enerzijds culturele verworvenheden van sociale voorzieningen wil handhaven, maar anderzijds de kosten van voorzieningen moet beperken, omdat bedrijven gemakkelijker over grote afstanden heen kunnen organiseren, en daarmee activiteiten kunnen plaatsen waar ze het meest rendabel kunnen worden verricht.

Regeringen worden aldus gedreven tot onderlinge "beleidsconcurrentie" die dreigt te leiden tot afbraak van sociale voorzieningen. Het antwoord hierop is dat we moeten zoeken naar die activiteiten waar afstand nog wel belangrijk is. Een creatieve bezinning op ons begrip van afstand vormt een hoge prioriteit. Afstand doet er niet meer toe, als je weet met wie je waarover hoe wilt communiceren. Dat geldt voor het doorgeven van blauwdrukken of ontwerpen. Het geldt niet voor samenwerking in ontwikkeling, waar frequentie en toeval van contact een grotere rol spelen. Het uitzoeken en stimuleren van ruimtelijke patronen van samenwerking in ontwikkeling vergt organisatie in de vorm van een industriebeleid.

In de huidige fase is het denkbeeld van op zichzelf staande ondernemingen die of wel met elkaar concurreren ofw'el op afstand van elkaar transacties met elkaar plegen verouderd. Daarmee komt het begrip markt op de helling te staan. Er tekenen zich velerlei vormen af van vormen van organisatie "tussen markt en hiërarchie": in velerlei vormen van samenwerking tussen partijen die deels een gemeenschappelijk 
en deels een strijdig belang hebben. Het inzicht groeit dat een markt ook een vorm van organisatie is. In die zin dat voor transacties tussen marktpartijen allerlei "instituties" nodig zijn om problemen van zoeken, afstemming, controle en risico te voorkomen. Informatie niet alleen over prijs maar ook over kwaliteit van vraag en aanbod. Afstemming van technische specificaties. Standaards voor rapportage en financiële waardering, ter beoordeling van kwaliteit en onzekerheid. Een stabiele munt en toezicht van een centrale bank. Wettelijke regelingen voor eigendom en contract. Toezicht op rechtszekerheid en -gelijkheid in de toepassing daarvan. Maar omdat geen contract volledig kan zijn, ook een basis in ethische normen en waarden voor "fatsoenlijk" economisch verkeer. Het weghalen van obstakels voor vernieuwing door gevestigde belangen en ideeën. En het faciliteren van netwerken van activiteiten die elkaar stimuleren en versterken. Bijvoorbeeld in de hierboven genoemde samenwerking in ontwikkeling.

We nemen veel van deze organisatie stilzwijgend en als vanzelfsprekend aan, omdat het gaat om een vertrouwde erfenis uit het verleden. Dat zij niet vanzelfsprekend is, en hoe zeer zij nodig is voor markten, blijkt op indringende wijze uit de moeizame ontwikkeling van markten in voormalige Oostblok landen.

Er is derhalve een markt voor organisatie. Praktijkmensen en onderzoekers die van wanten weten in de organisatie van markt en technologie. Met gebruik van technologie, en met oog voor een nieuwe interpretatie van ruimte en tijd. Dat vergt combinaties van bedrijfskunde, economie en ruimtelijke wetenschap. Zoals in de recent tot ontwikkeling gekomen onderzoekschool van de drie op die vakgebieden gerichte faculteiten aan de Rijksuniversiteit te Groningen. 